17. Kety, S. S.: Circulation and metabolism of human brain in health and diseases. Amer. J. Med., 8: 205 (1950).

18. Kety, S. S.: General metabolism of the brain in vivo. In: D. Richter: Metabolism of the Nervous System, pp. 221-236 (Pergamon Press, New York, 1957).

19. Kety, S. S., and Schmidt, C. F.: Nitrous oxide method for the quantitative determination of cerebral blood flow in man. J. Clin. Invest., 27: 476 (1948).

20. Kraus, H., Schlenker, S., and Schwedesky, D.: Developmental changes of cerebral ketone body utilization in human infants. Hoppe-Seyler's Z. Physiol. Chem., 355: 164 (1974).

21. Mehta, S., and Chakravarti, R. N.: Effect of protein malnutrition on various regions of weaning rat brain. Indian J. Med. Res., 61: 461 (1973).

22. Mehta, S., Teja, J. S., Thukural, S., Wig, N. N., and Pasricha, S.: Protein calorie malnutrition in children-A follow-up study. Indian J. Med. Res., 63: 576 (1975).

23. Mönckeberg, F., Beas, F., Horwitz, I., Dabancens, A., and Gonzalez, M.: Oxygen consumption in infant malnutrition. Pediatrics, 33: 554 (1964).

24. Owen, O. E., Morgan, A. P., Kemp, H. G., Sullivan, J. M., Herrera, M. G. and Cahill, G. F.: Brain metabolism during fasting. J. Clin. Invest., 46: 1589 (1967).

25. Sacks, W.: Cerebral metabolism of isotopic lipid and protein derivatives in normal human subjects. J. Appl. Physiol., 12: 311 (1958).

26. Stoch, M. B., and Smythe, P. M.: Does undernutrition during infancy inhibit brain growth and subsequent intellectual development? Arch. Dis. Childhood, 38: 546 (1963)

27. Stone, W. E., Tews, J. K., Whistler, K. E., and Brown, D. J.: Incorporation of carbon from glucose into cerebral amino acids, proteins and lipids, and alterations during recovery from hypoglycemia. J. Neurochem., 19: 321 (1972).

28. Swaiman, K. F., Daleiden, J. M., and Wolfe, R. N.: The effect of food deprivation on enzyme activity in developing brain. J. Neurochem., 17: 1387 (1970)

29. Udani, P. M.: Neurological manifestations in kwashiorkor. Indian J. Child Health, 9: 103 (1960).

30. Van Slyke, D. D., and Neill, J. A.: The determination of gases in blood and other solutions by vacuum extraction and manometric measurement. J. Biol. Chem., 61: 523 (1924).

31. Winick, M.: Malnutrition and brain development. J. Pediat., 74: 667 (1969).

32. Winick, M.: Nutrition and cell development. Fed. Proc., 29: 1510 (1970).

33. Winick, M., and Noble, A.: Cellular response in rats during malnutrition at various ages. J. Nutr., 89: 300 (1966)

34. Winick, M., and Rosso, P.: The effect of severe early malnutrition on cellular growth of human brain. Pediat. Res., 3: 181 (1969).

35. The technical assistance of Mr. S. P. Singh, Mr. S. C. Sharma and Mr. Nand Kishore is gratefully acknowledged. We also wish to thank Drs. Pandit, Mrs. S. Kaushik, and M. Khur from the Department of Anaesthesiology, Postgraduate Institute of Medical Education and Research for their assistance.

36. This research was supported by United States Public Health Service Grants 01-041-N and NS-12256 (Special Foreign Currency Project).

37. Requests for reprints should be addressed to: J.. H. Menkes, M.D., 9615 Brighton Way, Beverly Hills, Calif. (USA)

38. Received for publication March 26, 1976.

39. Accepted for publication September 10, 1976.
Asparate transcarbamylase cerebellum developmental biochemistry nucleic acid synthesis pyrimidine biosynthesis thymidine kinase thymidylate synthetase uridine kinase undernutrition

\title{
Pyrimidine Metabolism during Restorative Brain Growth after Neonatal Undernutrition in the Rat
}

\author{
MORTON E. WEICHSEL, JR., ${ }^{(27)}$ AND BRIAN R. CLARK \\ Departments of Pediatrics and Psychiatry, Harbor General Hospital, UCLA School of Medicine, Torrance, \\ California, USA
}

\section{Summary}

Three litters of 20 Wistar rat pups each were maintained until age 6 days at which time only the 4 lightest and 4 heaviest pups from each litter were left with the mother until age 13 days. Three control litters of eight pups each were also maintained for 13 days. At that time, the undernourished light pups showed body weight, cerebellar weight, and cerebellar DNA, respectively, of $79.2 \%, 86.6 \%$, and $90.4 \%$ compared with a "combined control" group consisting of control pups plus undernourished heavy pups which were statistically indistinguishable with regard to these three measurements. After the week of "catchup" or restorative body and brain growth, activities of enzymes from metabolic pathways leading to pyrimidine and nucleic acid biosynthesis were measured in cerebella from all three groups (control, undernourished heavy, and undernourished light). The salvage pathway enzyme thymidine kinase (TK) and the interconversion pathway enzyme thymidylate synthetase (TS) in the undernourished light group showed significant elevations of $32 \%$ and $11 \%$, respectively, above activity in the combined control group. The salvage pathway enzyme uridine kinase (UK) and the de novo pathway enzyme aspartate transcarbamylase were not significantly difierent in cerebella from these two groups. The significant elevation in TK and TS in undernourished pups suggests that these enzymes are critical for restorative brain growth. The significant elevation of TS indicates that the interconversion pathway converting available uridylate, a ribonucleotide, to thymidylate, a deoxyribonucleotide, is activated in order to augment DNA biosynthesis.

\section{Speculation}

These findings suggest that certain metabolic pathways may have special importance in restorative brain growth. These biochemical relationships may be extrapolated to the condition of human perinatal undernutrition and restorative brain growth whereby it might be expected that certain critical enzymes and metabolic pathways may be selectively affected.

The ability of the brain to undergo restorative or "catch-up" growth following undernutrition during critical periods of development has recently become a subject of increasing interest. Although somatic growth acceleration following illness or under- 
nutrition is well known (13), little has been reported concerning the potential for restorative growth in the undernourished developing brain, and the possible biochemical mechanisms involved. The rat cerebellum, which develops during the first 3 extrauterine weeks and attains its maximum rate of growth during the second week, is markedly subject to impaired development by stimuli such as undernutrition (6), hyperthyroidism (6), hypothyroidism (6), and hyperglucocorticoidism (18). Winick et al. (21) showed that the cerebella of rats undernourished in the suckling period show a marked decrease in DNA (cell number) at maturity, but if the undernourished pups are refed by 9 days of extrauterine life, the cerebellar cell number will increase to that of normal control subjects by the time of weaning at 3 weeks of age.

Restorative brain growth following recovery from illness in human premature infants has recently been described by Sher and Brown (14) who noted a nonhydrocephalic period of increasing rate of head growth between the third and the seventh postnatal week following illness, which corresponded to increased nutritional intake and improvement in clinical state. Study of the biochemistry relating to cell division during "catchup" growth has thus far been confined to the diver (8).

There is a known relationship between cerebellar cell division and activities of the enzymes involved in pyrimidine biosynthesis (20). In a study of glucocorticoid-induced cerebellar and somatic growth suppression in the rat, an increase in the activity of TK was noted during the later period of "catch-up" growth (18). This enzyme represents a salvage (reutilization) pathway for incorporation of preformed pyrimidine deoxyribonucleosides into newly formed DNA. Because thymidine kinase is thought to be part of an essential regulatory mechanism in rate of brain DNA synthesis (17), the present study was designed to determine the effect of catch-up growth on thymidine kinase as well as other cerebellar enzymes from salvage, de novo, and interrelating pathways for pyrimidine biosynthesis. These pathways are shown in Figure 1.

\section{MATERIALS AND METHODS}

Wistar rats were used in this study (23). Pregnant rats were transferred to the animal care facility, Harbor General Hospital, to await parturition. All mothers were fed white rat growth chow obtained from Simonsen Laboratories, Gilroy, Calif. (23). Pups born within a $12-\mathrm{hr}$ period from eight mothers were randomly mixed, and subsequently 20 pups each were assigned on the day of birth to three mothers who were judged to be especially attentive. Excessively large or small pups were excluded. Three control litters of 8 rats each and two spare litters of 12 pups each were maintained. Pups were substituted from the spare litters for

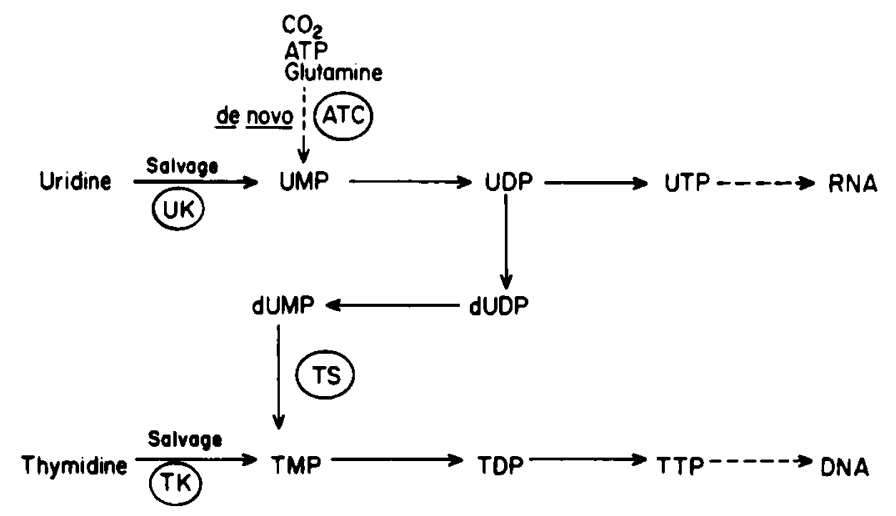

Fig. 1. De novo, salvage, and interconversion pathways for incorporation of pyrimidine nucleotides into nucleic acids. UMP, UDP, UTP, and TMP, TDP, TIP represent uridine and thymidine mono-, di-, and triphosphate, respectively. UK, ATC, TK, and TS represent uridine kinase, aspartate transcarbamylase, thymidine kinase, and thymidylate synthetase, respectively. dead animals in the larger litters, but were not used for biochemical determinations. The litters of 20 pups were maintained until age 6 days, at which time the lightest 4 and the heaviest 4 of the original pups were designated undernourished light and undernourished heavy, respectively. These 8 pups were left with the mother while the remaining 12 middle-sized or substituted pups were removed permanently. The three experimental litters were thereafter maintained at 8 pups each until day 13 and were weighed daily through day 12 . On day 13 , control and experimental pups were decapitated and the cerebellum was rapidly removed and weighed.

The cerebellum was homogenized in a medium consisting of sucrose $(0.25 \mathrm{M})$, Tris, $\mathrm{pH} 7.6(0.1 \mathrm{M})$, magnesium-ATP $(0.015$ M MgSO $4 / 0.01 \mathrm{M}$ ATP), thymidine $50 \mu \mathrm{M}$, dithiothreitol 1 $\mathrm{mM}$, glutamine $3 \mathrm{mM}$. This medium was designed for the combined assay of TK, TS, UK, and aspartate transcarbamylase (ATC). From each crude homogenate, an aliquot was withdrawn for DNA determination. The remaining homogenate was then centrifuged at $35,000 \times g$ at $5^{\circ}$ for $20 \mathrm{~min}$. The enzyme assays and determination of protein content were performed on the supernatant solution.

Thymidine kinase was assayed by a procedure combining the method of Yamagami et al. (22) and Breitman (2), as modified for use in our laboratory (19). Other activities were assayed as follows: ATC by a modification of the method described by Bethell et al. (1), UK by the Herbst et al. (7) modification of the method of Sköld (15), and thymidylate synthetase as described by Kawai and Hillcoat (9). Radioactivity was measured in a scintillation spectrometer (24).

Protein was determined on samples of supernatant solution using the Oyama and Eagle (12) modification of the method of Lowry et al. (11).

DNA was determined using the modification by Giles and Myers (5) of the method of Burton (3).

Statistical analysis was applied to data points for undernourished heavy and light animals by Student's $t$-test for two groups of independent measurements.

\section{RESULTS}

All data are presented in Tables 1 and 2. There was no significant difference $(P<0.05)$ between any of the means of the undernourished heavy group measurements and the mean of the corresponding control group measurement (Table 2). Using body weight, cerebellar wet weight, and cerebellar DNA content as determinants of nutritional status (19), the undernourished heavy group at day 13 was therefore indistinguishable from the control group. These two groups were then combined to form a "combined control" group for day 13. The means of the cerebellar measurements and enzyme activities in the undernourished light group were then compared with the corresponding means for the combined control group in order to assess restorative cerebellar growth after nutritional deprivation (Table 2).

Body weights of the heaviest undernourished and the lightest undernourished pups from oversized litters (Table 1) are compared in Figure 2 with mean weights of normally nourished

Table 1. Body weight (grams) of undernourished and control groups at ages 6 and 12 days ${ }^{1}$

\begin{tabular}{llcc}
\hline & No. & \multicolumn{1}{c}{6 days } & No. 12 days \\
\hline Control & $(12) 15.20 \pm 0.22$ & (12) $28.67 \pm 1.00$ \\
Undernourished & $(12) 12.90 \pm 0.21^{2}$ & (12) $29.18 \pm 0.66$ \\
$\quad$ heavy & $(84.8 \%)$ & $(102 \%)$ \\
$\begin{array}{l}\text { Undernourished } \\
\text { light }\end{array}$ & $(12) \quad 8.81 \pm 0.74^{2}$ & (12) $22.88 \pm 0.74^{2}$ \\
& & $(58.0 \%)$ & $(79.8 \%)$ \\
\hline
\end{tabular}

${ }^{1}$ Values expressed as mean \pm SEM. The number of values for each calculation is given in parentheses.

${ }^{2}$ Statistical significance between undernourished and control groups $(P<0.01)$ 
Table 2. Comparisons of body weight, cerebellar measurements, and enzyme activities after 1 week of catch-up growth

\begin{tabular}{|c|c|c|c|c|c|c|c|}
\hline & \multirow[b]{2}{*}{ Body weight, $\mathrm{g}$} & \multirow{2}{*}{$\begin{array}{c}\text { Cerebellar wet } \\
\text { weight, mg }\end{array}$} & \multirow{2}{*}{$\begin{array}{l}\text { Cerebellar } \\
\text { DNA, } \mu \mathrm{g}\end{array}$} & \multicolumn{4}{|c|}{ Enzyme activity ${ }^{1}$} \\
\hline & & & & TK, pmol & TS, pmol & ATC, nmol & UK, nmol \\
\hline Control $(n=12)$ & $28.67 \pm 1.00$ & $119.2 \pm 2.7$ & $1035 \pm 40$ & $48.7 \pm 4.0$ & $38.3 \pm 1.0$ & $18.8 \pm 0.7$ & $2.23 \pm 0.08$ \\
\hline $\begin{array}{l}\text { Undernourished } \\
\text { heavy }(n=12)\end{array}$ & $\begin{array}{c}29.18 \pm 0.66 \\
(102 \%)^{2}\end{array}$ & $\begin{array}{c}125.1 \pm 3.2 \\
(105 \%)\end{array}$ & $\begin{array}{c}1067 \pm 39 \\
(103 \%)\end{array}$ & $\begin{array}{r}42.6 \pm 4.0 \\
(87.5 \%)\end{array}$ & $\begin{array}{r}35.6 \pm 1.5 \\
(93.0 \%)\end{array}$ & $\begin{array}{c}19.5 \pm 0.5 \\
(104 \%)\end{array}$ & $\begin{array}{c}1.99 \pm 0.05 \\
(89.2 \%)\end{array}$ \\
\hline $\begin{array}{l}\text { Combined contr } \\
\mathrm{ol}^{3}(n=24)\end{array}$ & $28.92 \pm 0.59$ & $122.0 \pm 2.1$ & $1051 \pm 28$ & $45.1 \pm 2.9$ & $37.0 \pm 1.0$ & $19.1 \pm 0.4$ & $2.09 \pm 0.06$ \\
\hline $\begin{array}{l}\text { Undernourished } \\
\text { light }(n=12)\end{array}$ & $\begin{array}{c}22.88 \pm 0.74^{2.4} \\
(79.2 \%)\end{array}$ & $\begin{array}{c}105.6 \pm 1.2^{4} \\
(86.6 \%)\end{array}$ & $\begin{array}{c}957.7 \pm 30^{4} \\
(90.4 \%)\end{array}$ & $\begin{array}{c}55.8 \pm 3.0^{4} \\
(132 \%)\end{array}$ & $\begin{array}{c}41.2 \pm 1.3^{4} \\
(111 \%)\end{array}$ & $\begin{array}{c}20.2 \pm 1.4 \\
(106 \%)\end{array}$ & $\begin{array}{c}1.98 \pm 0.09 \\
(97.1 \%)\end{array}$ \\
\hline
\end{tabular}

1 Enzyme activity is expressed as mean value per min per $\mathrm{mg}$ protein $\pm \mathrm{SEM}$.

2 Percentage of control (undernourished heavy) or percentage of combined control (undernourished light).

${ }^{3}$ Means of combined control groups are means of control measurements plus undernourished heavy measurements.

- Indicates statistical significance at $P<\mathbf{0 . 0 5}$, between means of control and undernourished heavy or between means of combined control and undernourished light.

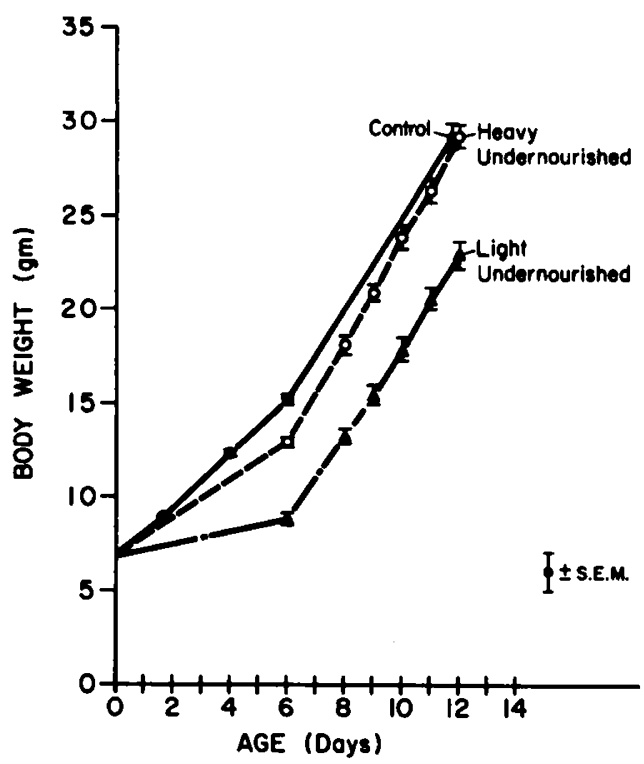

Fig. 2. Developmental curves for body weight of control rat pups raised from birth in litters of $8(-\bullet)$, as well as body weights of the 4 heaviest undernourised $\left(\mathrm{O}_{--} \mathrm{O}\right)$, and 4 lightest undernourished $(\Delta-\cdot-\Delta)$ pups from each of three litters containing 20 pups until age 6 days and thereafter containing only the 4 undernourished heavy and 4 undernourished light pups until time of death at day 13.

control pups. By age 6 days, the lightest pups in litters of 20 weighed $58.0 \%$ of normally nourished controls, whereas the heavy undernourished pups weighed $84.8 \%$ of controls. After the oversized litters were reduced from 20 to 8 animals on day 6 , both the heavy and light groups assumed an increased rate of somatic growth. By age 12 days, the undernourished light pups in the accelerated growth phase reached $79.8 \%$ of control weight, whereas the undernourished heavy group weighed $102 \%$ of control.

Figure 3 compares body weight, cerebellar wet weight, and cerebellar DNA (Table 2) from the combined control and undernourished light animals on day 13, after catch-up growth had been in effect for 1 week. Body weight in the undernourished light group was $79.2 \%$ of that in the combined control group. Cerebellar wet weight in the undernourished light group remained significantly decreased to $86.6 \%$ of that in the combined control group whereas cerebellar DNA in the undernourished light group remained significantly decreased to $90.4 \%$ of that in the combined control group.

In Figure 4, the activities of cerebellar TK, TS, ATC, and UK in the combined control and undernourished pups are compared

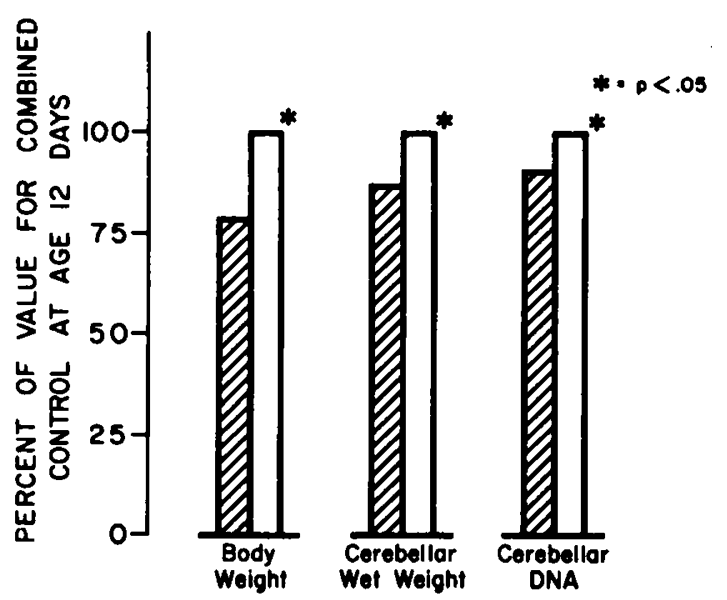

Fig. 3. Body weight, cerebellar wet weight, and cerebellar DNA from undernourished light rat pups expressed as a percentage of the values for combined controls at age 12 days, after 1 week of nutritional catch-up growth. Values for combined control pups (100\%), respectively, are: $28.92 \mathrm{~g}, 122.0 \mathrm{mg}, 1,051 \mu \mathrm{g}, P<0.05$.

after 1 week of catch-up growth. Activities of enzymes from the combined control group at age 13 days are depicted as $100 \%$, and for TK, TS, ATC, and UK, respectively, are $45.1 \mathrm{pmol} /$ $\mathrm{min} / \mathrm{mg}$ protein, $37.0 \mathrm{pmol} / \mathrm{min} / \mathrm{mg}$ protein, $19.1 \mathrm{nmol} / \mathrm{min} /$ $\mathrm{mg}$ protein, and $2.09 \mathrm{nmol} / \mathrm{min} / \mathrm{mg}$ protein. Activities of TK and TS in the undernourished light group were significantly greater by $32 \%$ and $11 \%$ than the respective activity in the combined control group. Activities of ATC and UK were not significantly dfferent in the two groups.

Figure 5 compares the normal cerebellar developmental spectra for the four enzymes as determined previously in this laboratory $(4,17,20)$. Enzyme activities noted at age 13 days in the present experiments are consistent with the values at age 13 days from these previously established developmental curves.

\section{DISCUSSION}

Although the oversized litter has been used often as a means to create experimental protein-calorie undernutrition in the rat, the majority of studies have not considered possible differences in nutritional status of animals raised in oversize litters. Weichsel and Dawson (19) have shown that there is a distinct spectrum of body weights in pups raised in litters of 20 by as early as 5 days, compared with control pups raised in litters of 8 . The heaviest of the undernourished 5-day-old pups in that study weighed $15 \%$ less than controls but neither cerebellar wet weight nor cerebellar DNA content (cell number) differed statistically from control 


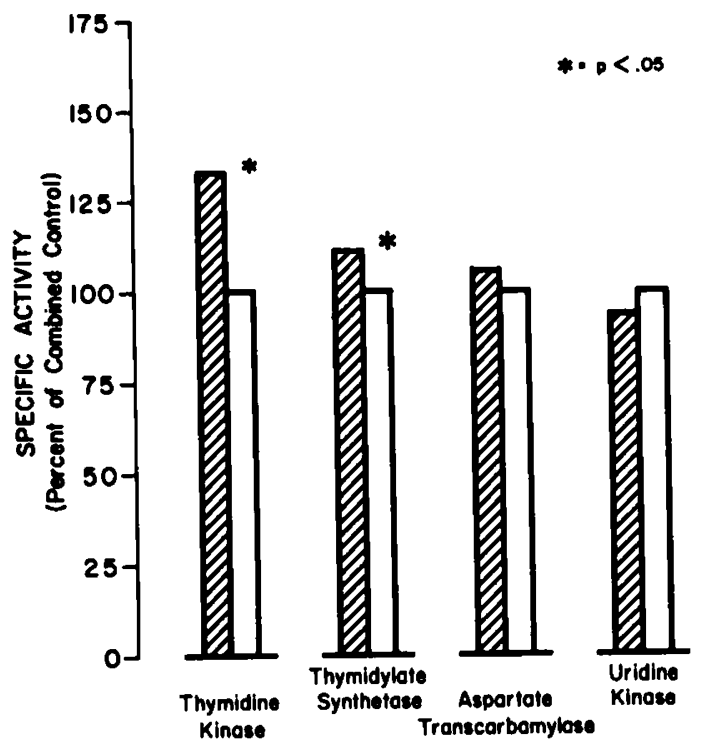

Fig. 4. Activities of thymidine kinase (TK), thymidylate synthetase (TS), aspartate transcarbamylase (ATC), and uridine kinase (UK) from cerebella of undernourished light rat pups at age 13 days after 1 week of catch-up growth, expressed as a percentage of activity from cerebella of combined control pups. Enzymes were assayed as described in "Materials and Methods." Absolute values for enzyme activity in combined control group (100\%), expressed per $\mathrm{mg}$ protein per $\mathrm{min} \pm \mathrm{SEM}$, were TK, $45.1 \pm 2.9 \mathrm{pmol} ; \mathrm{TS}, 37.0 \pm 1.0 \mathrm{pmol}$; ATC, $19.1 \pm 0.40 \mathrm{nmol}$; UK, $2.09 \pm 0.06 \mathrm{nmol}$.

values, suggesting that if cerebellar cell number is to be used as a criterion for the degree of undernutrition, the heaviest animals from oversized litters cannot be considered as undernourished. The middle-sized and lightest animals in the same oversized litters did show a significant stepwise decrease in cerebellar weight and cerebellar DNA content, indicating a spectrum in the deficit in cerebellar cell number corresponding to the degree of undernutrition in the smaller animals (19). These results led to the present experimental design, whereby the four largest pups in an oversized litter might be expected to show little effect of undernutrition on cerebellar DNA, and the most undernourished might show a considerable suppression of cerebellar DNA synthesis during the period of undernutrition. Removal of the middle-sized 12 pups from the litter at age 6 days and maintaining the litter at normal size until age 13 days thus allowed for "catch-up" growth using the same mother for both groups of pups in each litter during the critical period when cerebellar "catch-up" growth is still possible (21), and during which time all of the enzymes being studied show relatively high activity (Fig. 5).

Somatic weights at age 6 days of both the undernourished heavy and undernourished light pups (Table 1, Fig. 2) corresponded closely with relative values observed previously in 5day-old pups (19). The rate of somatic weight gain in each of the undernourished groups from birth through age 6 days was less than the rate of normal controls (Fig. 2). However, after the litter size was reduced, the rate of somatic weight gain for both groups appeared to increase, approximating that of controls by day 13 .

Somatic weight, cerebellar wet weight, and cerebellar DNA in the undernourished light pups remained significantly below that of the combined control pups at the time of death on day 13 $(79.2 \%, 86.6 \%$, and $90.4 \%$, respectively; Fig. 3). Data from previous studies using a similar model (19) suggest that deficits in cerebellar weight and DNA in the lightest animals from undernourished litters at age 5 days are markedly greater than the deficits noted in the present experiment after catch-up growth at 13 days. The present results thus indicate that in spite

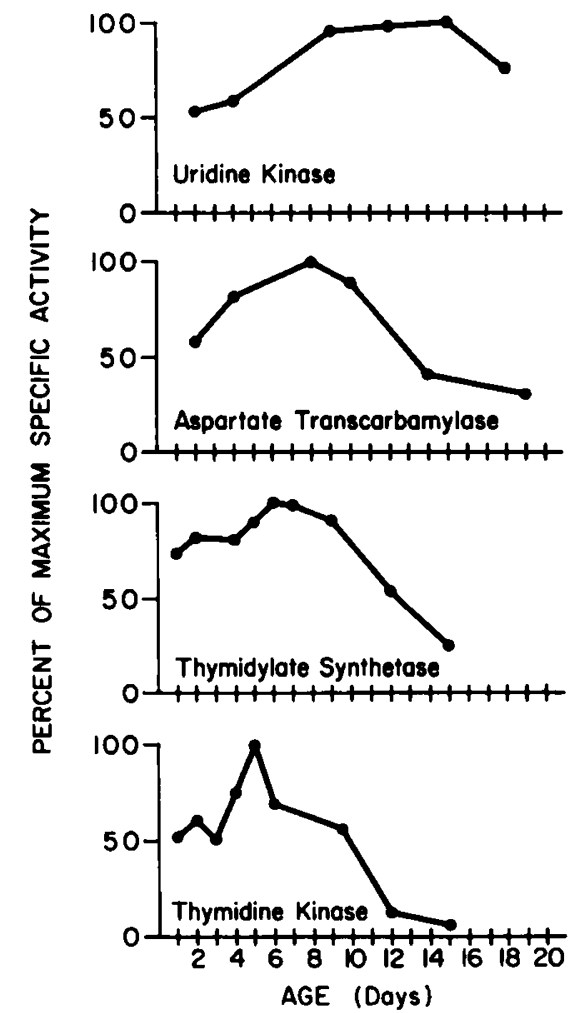

Fig. 5. Developmental curves for thymidine kinase (TK), thymidylate synthetase (TS), aspartate transcarbamylase (ATC), and uridine kinase (UK) in developing rat cerebellum $(4,17,20)$. The data are expressed as a percentage of maximal activity attained during rat cerebellar development. Maximal activities $(100 \%)$ were TK, $70.3 \mathrm{pmol} / \mathrm{min} / \mathrm{mg}$ protein; TS, $88.4 \mathrm{pmol} / \mathrm{min} / \mathrm{mg}$ protein; ATC, $8.23 \mathrm{nmol} / \mathrm{min} / \mathrm{mg}$ protein; UK, $2.83 \mathrm{nmol} / \mathrm{min} / \mathrm{mg}$ protein.

of the severe early growth deficit and subsequent increase in growth rate of the undernourished light animals from day 6 onward, cerebellar "catch-up" growth was not yet complete.

Studies of cell division in nutritional restorative growth have been confined largely to the liver in experimental animals. Jasper and Brasel (8) noted an increased level of tritiated thymidine incorporation into the liver of suckling rats after 3 days of refeeding in pups who were undernourished for the first 11 days of life. These authors also found DNA polymerase activity per cell to accelerate during days 1-3 of refeeding. Tagliamonte $e t$ al. (16), using a similar paradigm, found that refeeding after 7 and 10 days on a restricted diet produced an abrupt increase in liver TK activity which reached a maximal value after 2 days, before returning to normal after 4 days.

Recent evidence has accumulated indicating that there is a close correlation between the activity of enzymes involved in pyrimidine biosynthesis and the rate of cellular proliferation in mammals (10). Such incorporation of pyrimidines into nucleic acids involves a de novo pathway which uses the simple substrates $\mathrm{CO}_{2}$, ATP, and glutamine and leads to the formation of uridylic acid (10). Additionally, "salvage pathway" or reutilization pathway enzymes may incorporate pyrimidine nucleosides from exogenous sources or from endogenous breakdown of nucleic acids. Furthermore, uridylic acid may be converted into a range of pyrimidine nucleotides by a series of interconversion enzymes, many of which appear to be under complex metabolic control (10)

The rat cerebellum, which develops almost totally within the first 3 postnatal weeks and undergoes an 8-10-fold increase in DNA content during that period, has been used in our laboratory as a model to study cell division in general as well as to study cell division in an organ whose cells are mostly microneuron precursors. 
In a series of studies $(4,17,20)$, enzymes from de novo, salvage, and interconversion pathways (Fig. 1) have been shown to correlate in general with the rate of cerebellar cell division. Figure 5 demonstrates the time of peak activities of the salvage pathway enzymes TK and UK, as well as ATC and TS, representing the de novo and interconversion pathways, respectively. Activities of TK, TS, and ATC peak at approximately 5, 6, and 8 days, respectively, whereas UK reaches a plateau between ages 9 and 15 days. Because TK is felt to be an enzyme critical to both cerebellar and liver cell division $(16,17,19)$, and enzymes of each of the other involved pathways are known to be affected by hormonal stimuli during development (4), we elected to study this group of enzymes during brain catch-up growth. Cerebellar TK activity after a week of catch-up growth in the lightest pups from undernourished litters was $32 \%$ higher than the activity found in a combined control group comprised of control pups and the heaviest pups from the original oversized litters. This increase in TK activity at a time when the normal developmental curve for TK is declining suggests the possibility that TK is a critical enzyme for restorative growth in brain as well as liver, and supports the possibility that in glucocorticoid-treated rat pups (18), the increase in TK activity after 9 days of steroidinduced growth suppression represented an attempt at restorative growth.

The finding that cerebellar TS activity was elevated significantly in the light subgroup of undernourished animals during catch-up growth compared with the combined control group (Fig. 4) suggests that this enzyme, from the interconversion pathway (UMP $\rightarrow$ UDP $\rightarrow$ dUDP $\rightarrow$ TMP) which converts uridine monophosphate to deoxythymidine monophosphate (Fig. 1 ), acts as a shunt during catch-up brain growth, facilitating the conversion of available uridylate to thymidylate, in order to supply pyrimidine deoxyribonucleotides for increased DNA biosynthesis. The data suggest that TS is also a critical enzyme for restorative brain growth. The failure to detect a significant difference in ATC at this stage of catch-up growth suggests that an interconversion of deoxyuridine monophosphate to deoxythymidine monophosphate does not require increased activity of de novo pathway enzymes. Uridine kinase, which was also noted to be unaffected during catch-up cerebellar growth (Fig. 4), is felt to be related to RNA synthesis (10) as well as the maintenance of nondividing cells (20). Although newly formed cells during catch-up growth must synthesize DNA and RNA, the level of UK activity remains high throughout cerebellar development (Fig. 5) and, therefore, may not require enhancement.

Although there are many factors which contribute to brain growth, it is recognized that cell division continues to be active in the human brain during the perinatal period (18). Sher and Brown (14) have recently documented for the first time a pattern of catch-up brain growth occurring in the human premature infant who has recovered from sickness. Thus, the experiments described herein have a direct relevance to the biochemistry relating to cell division in human restorative brain growth and it is apparent that further studies involving the biochemistry of restorative growth may be rewarding.

\section{CONCLUSION}

In order to study the activity of enzymes from metabolic pathways leading to biosynthesis of pyrimidines and nucleic acids during nutritional catch-up growth of the brain, three litters of 20 rat pups were maintained for 6,days after which the 4 lightest (designated undernourished light) and 4 heaviest (designated undernourished heavy) pups from each litter were left with the mother in a litter of 8 in order to permit catch-up growth for 1 week. By day 13, the undernourished light group had not reached the somatic weight of control pups, whereas the body weight of the undernourished heavy group was restored. Growth in both undernourished subgroups had assumed an increased rate. Although values for somatic weight, cerebellar wet weight, and cerebellar DNA in the undernourished light subgroup re- mained significantly below control after 1 week of catch-up growth, cerebellar thymidine kinase and thymidylate synthetase activity in the undernourished light pups were significantly elevated over activity in the control pups. These results suggest that thymidine kinase and thymidylate synthetase may be critical enzymes for restorative brain growth and that such restorative brain growth after neonatal undernutrition may activate an interconversion pathway which shunts available uridylate to thymidylate. Results from the use of this experimental model for restorative or catch-up brain growth emphasize the importance of further biochemical studies relating to this nutritional condition which had been described recently in human premature infants.

\section{REFERENCES AND NOTES}

1. Bethell, M. R., Smith, K. E., White, J. S., and Jones, M. E.: Carbamyl phosphate: An allosteric substrate for aspartate transcarbamylase of Escherichia coli. Proc. Nat. Acad. Sci. U.S.A., 60: 1442 (1968).

2. Breitman, T. R.: The feedback inhibition of thymidine kinase. Biochim. Biophys. Acta 67: 153 (1963).

3. Burton, K.: A study of the conditions and mechanisms of the diphenylamine reaction for the colorimetric estimation of deoxyribonucleic acid. Biochem. J. 62: 315 (1956).

4. Clark, B. R., and Weichsel, M. E., Jr.: Submitted for publication.

5. Giles, K. W., and Myers, A.: An improved diphenylamine method for estimation of deoxyribonucleic acid. Nature, 206: 93 (1965).

6. Gourdon, J., Clos, J., Coste, C., Dainat, J., and Legrand, J.: Comparative effects of hypothyroidism, hyperthyroidism, and undernutrition on the protein and nucleic acid contents of the cerebellum in the young rat. J. Neurochem, 21: 861 (1973).

7. Herbst, J. J., Hurwitz, R., Sunshine, P., and Kretchmer, N.: Effect of colchicine on intestinal disaccharidases: Correlation with biochemical aspects of cellular renewal. J. Clin. Invest., 49: 530 (1970).

8. Jasper, H. C., and Brasel, J. A.: Rat liver DNA synthesis during the catch-up growth of nutritional rehabilitation. J. Nutr., 104: 405 (1974).

9. Kawai, M., and Hillcoat, B. L.: Non-enzymatic exchange of tritium from (5$\left.{ }^{3} \mathrm{H}\right)$ deoxyuridylate in the thymidylate synthetase assay. Anal. Biochem. 58: 404 (1974).

10. Levine, R. L., Hoogenraad, N. J., and Kretchmer, N.: A review: Biochemical and clinical aspects of pyrimidine metabolism. Pediat. Res., 8: 724 (1974).

11. Lowry, O. H., Rosebrough, N. J., Farr, A. L., and Randall, R. J.: Protein measurement with the Folin phenol reagent. J. Biol. Chem., 193: 265 (1951).

12. Oyama, V. I., and Eagle, H.: Measurement of cell growth in tissue culture with a phenol reagent (Folin-Cicaltreau). Proc. Soc. Exp. Biol., 91: 305 (1956).

13. Prader, A., Tanner, J. M., and Von Harnach, G. A.: Catch-up growth following illness or starvation. J. Pediat., 62: 646 (1963).

14. Sher, P. K., and Brown, S. B.: A longitudinal study of head growth in preterm infants. Il. Differentiation between 'catch-up' head growth and early infantile hydrocephalus. Develop. Med. Child. Neurol., 17: 711 (1975).

15. Sköld, $O$.: Uridine kinase from Ehrlich ascites tumor: Purification and properties. J. Biol. Chem., 235: 3237 (1960).

16. Tagliamonte, B., Benedetti, P. C., and Spadoni, M. A.: Effects of refeeding on liver thymidine kinase activity of food restricted suckling rats. Nutr. Rep. Int., 5: 305 (1972)

17. Weichsel, M. E., Jr.: Effect of thyroxine on DNA synthesis and thymidine kinase activity during cerebellar development. Brain Res., 78: 455 (1974).

18. Weichsel, M. E., Jr.: Glucocorticoid effect upon thymidine kinase in the developing cerebellum. Pediat. Res., 8: 843 (1974).

19. Weichsel, M. E., Jr., and Dawson, L.: Effects of hypothryoidism and undernutrition on DNA content and thymidine kinase activity during cerebellar development in the rat. J. Neurochem., 26(4): 675 (1976).

20. Weichsel, M. E., Jr., Hoogenraad, N. J., Levine, R. L., and Kretchmer, N. Pyrimidine biosynthesis during development of rat cerebellum. Pediat. Res., 6: 682 (1972).

21. Winick, M., Fish, I., and Rosso, P.: Cellular recovery in rat tissues after a brief period of neonatal malnutrition. J. Nutr., 95: 623 (1968).

22. Yamagami, S., Mori, K., and Kawakita, Y.: Changes of thymidine kinase in the developing rat brain. J. Neurochem., 19: 369 (1972).

23. Simonsen Laboratories, Gilroy, Calif.

24. Nuclear Chicago model $8912 \mathrm{~A}$ scintillation spectrometer.

25. The authors gratefully acknowledge the technical assistance of Mrs. Shirley Guo.

26. This research was supported by Harbor General Hospital General Research Support Grant GR-2076 and National Institutes of Health Grant HD 09277-02 from the United States Public Health Service (to Dr. Weichsel), and by the Foundation's Fund for Research in Psychiatry, Grant 72-550 (to Dr. Clark).

27. Requests for reprints should be addressed to: M. E. Weichsel, Jr., M.D., Department of Pediatrics, Harbor General Hospital, UCLA School of Medicine, 1000 West Carson St., Torrance, Calif. 90509 (USA).

28. Received for publication May 26, 1976.

29. Accepted for publication September 9, 1976 